\title{
Respon Lima Kultivar Kentang (Solanum tuberosum L.) Terhadap Perlakuan Manitol pada Kultur In Vitro
}

\section{Response of five potatoes (Solanum tuberosum L.) cultivars to mannitol treatments In Vitro culture}

\author{
Winna Firdawati ${ }^{1}$, Farida Damayanti ${ }^{2}$, Suseno Amien ${ }^{2}$, dan Warid Ali \\ Qosim $^{2}$ \\ ${ }^{1}$ Alumnus Program Studi Agroteknologi Fakultas Pertanian Universitas \\ Padjadjaran \\ ${ }^{2}$ Program Studi Agroteknologi Fakultas Pertanian Universitas Padjadjaran
}

\begin{abstract}
Potato is one of the vegetable commodities that potentially use as a source of carbohydrate and could be developed to support food diversification program. Global climate changes that lead to extreme climate change could cause some agricultural problem, i.e., drought stress. It is necessary to develop drought-tolerant cultivar as one of the options to solve the problem. The objective of this research was to identify the level of drought stress in five potato cultivars by observing the response of those cultivars to mannitol in vitro culture. The experiment was conducted at Tissue Culture Plant Breeding Laboratory, Faculty of Agriculture, Universitas Padjadjaran, on May 2014 to June 2014. The experiment was arranged in a factorial, completely randomized block design with two factors. The first factor was potato cultivar (five levels), consisted of Granola, Atlantik, Andina, Ping 06, and Merbabu 17. The second factor was mannitol concentration (five levels), consisted of 0.0 M, 0.1 M; 0.2 M; 0.3 M, and $0.4 \mathrm{M}$. The results showed that there was no interaction between potato cultivar and mannitol concentration in all traits observed. Number of leaves, number of nodes, number of roots, root length were independently affected by cultivar and mannitol concentration, meanwhile plantlet height, chlorophyll concentration were only independently affected by mannitol concentration. It was also showed that mannitol concentration of $0.4 \mathrm{M}$ decreased plantlets height, a number of leaves, and a number of roots in potato cultivars Granola, Atlantik, Andina, Ping 06 dan Merbabu 17.
\end{abstract}

Keywords: drought stress, in vitro, mannitol, potato

\begin{abstract}
Abstrak: Kentang adalah salah satu komoditas sayuran yang memiliki potensi sebagai sumber karbohidrat, sehingga dapat menunjang program diversifikasi pangan. Perubahan iklim global mengakibatkan terjadinya perubahan iklim yang ekstrim, salah satunya adalah cekaman kekeringan. Oleh karena itu dibutuhkan adanya varietas unggul kentang yang toleran terhadap kekeringan. Percobaan ini bertujuan untuk mengetahui respon lima kultivar kentang terhadap perlakuan penambahan manitol pada media kultur in vitro sebagai upaya identifikasi awal tingkat toleransi cekaman kekeringan. Percobaan dilaksanakan di Laboratorium Kultur Jaringan Pemuliaan Tanaman Fakultas Pertanian Universitas Padjadjaran pada bulan Mei sampai Juni 2014. Metode penelitian yang digunakan adalah Rancangan Acak Kelompok Faktorial yang terdiri dari dua faktor, diulang tiga kali. Faktor pertama adalah kultivar kentang (lima taraf), yaitu Granola, Atlantik, Andina, Ping O6 dan Merbabu 17. Faktor kedua adalah konsentrasi manitol (lima taraf), yaitu o M; 0.1 M; 0.2 M; 0.3 M; dan 0.4 M. Analisis data dengan menggunkana uji-F dan dilanjutkan dengan uji Duncan taraf $5 \%$. Hasil penelitian menunjukkan bahwa tidak terdapat interaksi antara konsentrasi manitol dan kultivar kentang pada seluruh karakter yang diamati. Karakter yang diamati selama percobaan hanya dipengaruhi secara mandiri kultivar pada karakter jumlah daun, jumlah buku planlet, jumlah akar, panjang akar, sedangkan pengaruh mandiri konsentrasi manitol adalah karakter jumlah daun, jumlah buku planlet, tinggi tanaman, konsentrasi klorofil, jumlah akar, panjang akar. Konsentrasi manitol 0.4 M mengakibatkan penurunan penampilan untuk karakter tinggi planlet, jumlah daun, jumlah akar pada kultivar kentang Granola, Atlantik, Andina, Ping 06 dan Merbabu 17.
\end{abstract}

Kata kunci: cekaman kekeringan, kentang, manitol 


\section{Pendahuluan}

Kentang (Solanum tuberosum L.) merupakan salah satu komoditas yang diprioritaskan diantara komoditas sayuran lain karena memiliki potensi sebagai sumber karbohidrat dalam menunjang program diversifikasi pangan (Karjadi, 2006). Ketersediaan kentang di Indonesia belum mencukupi karena kebutuhan kentang yang begitu tinggi serta tidak diimbangi oleh produksi kentang yang mencukupi di Indonesia. Penyebab penurunan produktivitas kentang adalah banyaknya faktor pembatas yang terjadi pada budidaya kentang, sehingga produksi kentang belum dapat memenuhi kebutuhan konsumsi kentang di Indonesia.

Salah satu faktor pembatas budidaya kentang yaitu perubahan iklim dan suhu yang ekstrem. Menurut Rubatzky dan Yamaguchi (1998), perubahan iklim yang ekstrem, akan mempengaruhi terhadap perkembangan cuaca, curah hujan, kelembapan dan ketersediaan air. Laju fotosintesis kentang mengalami kemunduran pada saat kadar air tanah habis, karena kentang merupakan tanaman yang peka terhadap cekaman kekurangan air. Mengatasi permasalahan budidaya kentang akibat ketersediaan air yang tidak menentu, perlu adanya varietas unggul kentang yang toleran terhadap kekeringan. Perakitan varietas unggul dilakukan melalui tahap pengumpulan plasma nutfah yang dimiliki, kemudian dilakukan identifikasi karakter yang diinginkan yaitu memiliki karakter toleran terhadap cekaman kekeringan. Identifikasi karakter toleran kekeringan dapat dilakukan di lapangan maupun di laboratorium secara in vitro.

Manitol merupakan larutan yang digunakan untuk mempertahankan stabilitas sel dan mengontrol potensial air dalam media tanaman. Manitol adalah gula alkohol yang mengendalikan potensi osmotik dalam media tanam untuk mensimulasi kondisi cekaman kekeringan. Gula alkohol disintesisdari hasil produk fotosintesis tanaman. Gula alkohol memiliki sifat sebagai zat terlarut yang kompatibel, sehingga gula alkohol sering terlibat untuk menyesuaikan osmotik sel dalam memainkan peran yang penting dibawah tekanan osmotik (Zang dan Komatsu, 2007). Vitova et al. (2002) menyatakan bahwa manitol dapat mendukung pertumbuhan tanaman seledri pada media in vitro dengan konsentrasi yang rendah. Konsentrasi manitol lebih tinggi dari kadar glukosa tanaman, maka manitol yang terakumulasi dalam jaringan akan menurunkan tekanan potensial air sesuai dengan kemampuannya sebagai stress osmotik yang memberikan dampak sebagai cekaman

kekeringan bagi tumbuhan.

\section{Bahan Dan Metode}

Percobaan dilaksanakan di Laboratorium Kultur Jaringan Pemuliaan Tanaman Fakultas Pertanian Universitas Padjadjaran. Percobaan terdiri dari dua tahap yaitu: (i) tahap pendahuluan, dan (ii) tahap perlakuan pada media MS dengan penambahan konsentrasi manitol. Tahap pendahuluan dilaksanakan pada bulan April 2014, sedangkan tahap perlakuan dilaksanakan pada bulan Mei - Juni 2014.

Metode Penelitian yang digunakan adalah metode eksperimen dengan menggunakan Rancangan Acak Kelompok pola faktorial, terdiri dari dua faktor dan diulang tiga kali. Faktor pertama adalahkultivar kentang $(\mathrm{K})$ yang terdiri dari kultivar Granola (k1), Atlantik (k2), Andina (k3), Ping 06 (k4), Merbabu 17 (k5). Faktor kedua yaitu konsentrasi manitol, terdiri dari empat taraf yaitu, 0.0 M (m1); $0.1 \mathrm{M}(\mathrm{m} 2), 0.2 \mathrm{M}$ (m3); $0.3 \mathrm{M}(\mathrm{m} 4)$; 0.4 M (m5). Data tersebut dianalisis ragam untuk menguji nilai rata-rata suatu karakter yang berbeda nyata berdasarkan uji-F taraf $5 \%$ dan apabila perlakuan berbeda nyata pada taraf uji $\mathrm{F} 5 \%$, maka dilanjutkan dengan uji jarak berganda Duncan dengan taraf $5 \%$.

Media tahap pendahuluan terdiri dari bahan dasar media Murashige \& Skoog (MS), gula (30 g/L), agaragar $(8,5 \mathrm{~g} / \mathrm{L})$. Media tahap perlakuan terdiri dari media MS dan penambahan manitol dengan konsentrasi $0.1 \mathrm{M}$; $0.2 \mathrm{M}$; $0.3 \mathrm{M}$ dan $0.4 \mathrm{M}$, gula (30 $\mathrm{g} / \mathrm{L})$, agar-agar $(8.5 \mathrm{~g} / \mathrm{L})$.

Perbanyakan bahan tanam (eksplan) dilakukan pada tahap pendahuluan. Penanaman dilakukan dalam Laminar Air Flow (LAF). Eksplan tanaman kentang diambil dari stek mikro, berupa satu nodus yang sudah dikulturkan dan harus terbebas dari patogen dan bakteri. Penanaman eksplan pada tahap perlakuan diseragamkan pada umur sepuluh hari. Eksplan dipindah tanamkan ke media MS yang telah ditambah manitol sesuai konsentrasi perlakuan yang telah ditetapkan.

Pengamatan terdiri dari pengamatan penunjang dan pengamatan utama. Pengamatan penunjang terdiri dari pengamatan suhu dan kelembaban ruang kultur. Pengamatan utama terdiri dari karakter jumlah pertambahan buku tanaman, jumlah pertambahan daun, jumlah pertambahan tinggi tanaman, jumlah klorofil daun, jumlah akar, panjang akar, waktu menguning daun, skoring kerusakan planlet.

\section{Hasil Dan Pembahasan}

Pengamatan utama dilakukan pada awal memasuki tahap perlakuan pemberian manitol hingga akhir percobaan pada 6 Minggu Setelah Perlakuan (MSP). Berdasarkan uji F pada Tabel 1. menunjukkan bahwa tidak terdapat interaksi antara kultivar kentang dengan konsentrasi manitol pada semua karakter yang diamati. Kultivar kentang dan manitol secara mandiri berpengaruh pada semua karakter, kecuali karakter pertambahan tinggi planlet dan konsentrasi klorofil, kedua karakter tersebut hanya dipengaruhi faktor manitol secara mandiri. Karakterkarakter yang memiliki nilai uji F signifikan maka 
Tabel 1. Hasil Uji F Pada Karakter Pengamatan Utama

\begin{tabular}{|c|c|c|c|c|c|c|}
\hline \multirow[b]{2}{*}{ Sumber Variasi } & \multicolumn{6}{|c|}{ Pengamatan Utama } \\
\hline & $\begin{array}{c}\text { Pertambahan } \\
\text { jumlah buku } \\
\text { planlet }\end{array}$ & $\begin{array}{c}\text { Pertambahan } \\
\text { jumlah daun } \\
\text { planlet }\end{array}$ & $\begin{array}{l}\text { Pertambahan } \\
\text { tinggi planlet }\end{array}$ & $\begin{array}{c}\text { Konsentrasi } \\
\text { klorofil }\end{array}$ & $\begin{array}{c}\text { Jumlah } \\
\text { akar } \\
\text { terbentuk }\end{array}$ & $\begin{array}{l}\text { Panjang } \\
\text { akar } \\
\text { terbentuk }\end{array}$ \\
\hline Kultivar & $4.26^{*}$ & $6.96^{*}$ & $1.77^{\mathrm{tn}}$ & $1.09^{\mathrm{tn}}$ & $4.10^{*}$ & $2.17^{*}$ \\
\hline Manitol & $117.19^{*}$ & $135.36^{*}$ & $50.78^{*}$ & $3.05^{*}$ & $12.92^{*}$ & $45.12^{*}$ \\
\hline Kultivar x Manitol & $1.51^{\mathrm{tn}}$ & $1.24^{\mathrm{tn}}$ & 0.69 tn & 0.69 tn & $1.61^{\mathrm{tn}}$ & $1.87 \mathrm{tn}$ \\
\hline
\end{tabular}

Keterangan : * berbeda nyata pada taraf $5 \%$

tn tidak berbeda nyata pada taraf $5 \%$

dilakukan sebuah analisis secara lanjut dengan menggunakan uji jarak berganda Duncan pada taraf $5 \%$. Karakter warna daun dan skoring kerusakan planlet tidak dianalisis statistik.

Berdasarkan Tabel 2. terlihat bahwa kultivar Merbabu 17 memiliki jumlah buku planlet yang berbeda nyata dengan kultivar lainnya kecuali dengan kultivar Andina dan setiap konsentrasi manitol berbeda nyata pada pertambahan jumlah buku. Pembentukan buku atau nodus pada tanaman kentang dipengaruhi senyawa sitokinin (Husna dkk., 2014). Penambahan manitol dengan konsentrasi rendah memberikan pertambahan jumlah buku planlet paling banyak dibandingkan dengan penambahan manitol dengan konsentrasi tinggi. Konsentrasi manitol 0.4 M (Tabel 2) memiliki pertambahan jumlah buku terendah. Konsentrasi manitol yang sangat tinggi dapat menyebabkan tekanan osmotik yang sangat tinggi, sehingga membuat nutrisi yang tersedia pada media tidak dapat diserap dengan baik oleh jaringan tanaman (Roostika dkk., 2012).

Tabel 2. Pengaruh Mandiri Faktor Kultivar Kentangdan Konsentrasi Manitol pada Karakter Pertambahan Buku Planlet

\begin{tabular}{|c|c|}
\hline Kultivar & $\begin{array}{c}\text { Pertambahan Jumlah Buku } \\
\text { Planlet }\end{array}$ \\
\hline Granola $\left(\mathrm{k}_{1}\right)$ & $3.1 \mathrm{a}$ \\
\hline Atlantik $\quad\left(\mathrm{k}_{2}\right)$ & $2.7 \mathrm{a}$ \\
\hline Andina $\left(\mathrm{k}_{s}\right)$ & $3.6 \mathrm{ab}$ \\
\hline Ping $06 \quad\left(k_{4}\right)$ & $2.6 \mathrm{a}$ \\
\hline Merbabu $17\left(\mathrm{k}_{5}\right)$ & $3.9 \mathrm{~b}$ \\
\hline Konsentrasi Manitol & $\begin{array}{c}\text { Pertambahan Jumlah } \\
\text { Daun Planlet }\end{array}$ \\
\hline $0.0 \mathrm{M}\left(\mathrm{m}_{1}\right)$ & $6.7 \mathrm{e}$ \\
\hline $0.1 \mathrm{M}\left(\mathrm{m}_{2}\right)$ & $4.6 \mathrm{~d}$ \\
\hline $0.2 \mathrm{M}\left(\mathrm{m}_{3}\right)$ & $2.6 \mathrm{c}$ \\
\hline $0.3 \mathrm{M}\left(\mathrm{m}_{4}\right)$ & $1.5 \mathrm{~b}$ \\
\hline $0.4 \mathrm{M}\left(\mathrm{m}_{5}\right)$ & $0.5 \mathrm{a}$ \\
\hline
\end{tabular}

Keterangan: Nilai rata-rata yang ditandai dengan huruf yang sama pada kolom yang sama menunjukkan tidakberbeda nyata menurut uji jarak berganda duncan pada taraf $5 \%$
Karakter pertambahan jumlah daun planlet dipengaruhi secara sangat nyata oleh faktor kultivarkentang dan manitol secara mandiri (Tabel 1). Tabel 3 menunjukkan bahwa kultivar Merbabu 17 menghasilkan pertambahan jumlah daun planlet yang berbeda nyata dengan kultivar lainnya dan semua perlakuan manitol menghasilkan pertambahan jumlah daun yang berbeda nyata satu dengan lainnya. Hal ini dapat dilihat bahwa kutivar Merbabu 17 dapat menghasilkan jumlah daun terbanyak dibandingkan dengan kultivar lainnya. Perbedaan pertambahan jumlah daun tersebut diduga disebabkan oleh latar belakang genetik masing-masing kultivar berbeda. Menurut Wattimena dkk. (1992) morfogenesis pertumbuhan tanaman dari kultur jaringan dipengaruhi oleh kultivar sumber jaringan yang digunakan. Berdasarkan Tabel 3 terlihat bahwa semakin besar penambahan konsentrasi manitol pada media kultur akan memberikan dampak semakin rendah pertumbuhan jumlah daun planlet. Perlakuan konsentrasi manitol O.O M menghasilkan pertambahan jumlah daun terbesar dibandingkan dengan perlakuan konsentrasi manitol lainnya, sedangkan konsentrasi manitol o,4 M memiliki menghasilkan pertambahan jumlah daun terendah dibandingkan dengan perlakuan konsentrasi lainnya. Semakin tinggi konsentrasi manitol yang ditambahkan ke dalam media kultur memberikan dampak semakin rendah pertambahan jumlah daun planlet. Dunca et al. (1995) mengungkapkan bahwa penggunaan manitol sebagai stres osmotik pada kultur in vitro tanaman sorgum, mengurangi kemampuan regenerasi tanaman tersebut akibat penurunan potensial osmotik. Passioura et al. (1992) menjelaskan bahwa untuk mempertahankan pertumbuhan daun, diperlukan turgor yang baik tanpa tekanan stress akibat penurunan potensial, karena turgor memiliki peran yang penting dalam proses fisiologi daun. Jaringan tanaman yang terakumulasi oleh penurunan potensial osmotik air, memberikan penurunan kemampuan turgor untuk tetap bertahan pada kondisi stres air. 
Tabel 3.Pengaruh Mandiri Faktor Kultivar Kentang dan Konsentrasi Manitol Karakter Pertambahan Jumlah Daun

\begin{tabular}{lcc}
\hline \multicolumn{2}{c}{ Kultivar } & $\begin{array}{c}\text { Pertambahan Jumlah } \\
\text { Daun Planlet }\end{array}$ \\
\hline Granola $\left(\mathrm{k}_{1}\right)$ & $8.2 \mathrm{~b}$ \\
Atlantik $\left(\mathrm{k}_{2}\right)$ & $7.2 \mathrm{ab}$ \\
Andina $\left(\mathrm{k}_{3}\right)$ & $8.4 \mathrm{ab}$ \\
Ping 06 $\left(\mathrm{k}_{4}\right)$ & $6.7 \mathrm{a}$ \\
Merbabu $17\left(\mathrm{k}_{5}\right)$ & $10.4 \mathrm{c}$ \\
\hline Konsentrasi Manitol & $\begin{array}{c}\text { Pertambahan Jumlah } \\
\text { Daun Planlet }\end{array}$ \\
\hline O.0 M $\left(\mathrm{m}_{1}\right)$ & $20.6 \mathrm{e}$ \\
O.1 M $\left(\mathrm{m}_{2}\right)$ & $14.8 \mathrm{~d}$ \\
0.2 M $\left(\mathrm{m}_{3}\right)$ & $8.1 \mathrm{c}$ \\
0.3 M $\left(\mathrm{m}_{4}\right)$ & $6.9 \mathrm{~b}$ \\
0.4 M $\left(\mathrm{m}_{5}\right)$ & $1.5 \mathrm{a}$ \\
\hline
\end{tabular}

Keterangan: Nilai rata-rata yang ditandai dengan huruf yang sama pada kolom yang sama menunjukkan tidakberbeda nyata menurut uji jarak berganda duncan pada taraf $5 \%$

Karakter pertambahan tinggi planlet hanya dipengaruhi sangat nyata oleh faktor konsentrasi manitol secara mandiri. Berdasarkan Tabel 4 terlihat bahwa setiap konsentrasi manitol berbeda nyata untuk pertambahan tinggi planlet, kecuali pada konsentrasi manitol O,2 M dengan 0.3 M yang menghasilkan pertambahan tinggi planlet yang tidak berbeda nyata. Penambahan manitol pada media kultur memberikan pengaruh simulasi cekaman kekeringan pada semua kultivar kentang, Hal ini menunjukkan bahwa semakin tinggi konsentrasi manitol, semakin besar pula pengaruh cekaman kekeringan yang diberikan oleh manitol. Peningkatan konsentrasi manitol dalam media kultur yang terakumulasi, dapat menurunkan potensial air rendah, sehingga memberikan dampak negatif seperti, pertumbuhan tinggi tanaman terhambat, kelainan dalam reproduksi tanaman, dan daun menggulung (Mitoi et al., 2009).

Pengamatan konsentrasi klorofil dilakukan pada akhir pengamatan dengan mengambil sampel daun terbesar setiap kultivar pada setiap perlakuan. Karakter konsentrasi klorofil dipengaruhi secara nyata oleh konsentrasi manitol secara mandiri. BerdasarkanTabel 5 terlihat bahwa semua perlakuan manitol tidak berbeda nyata kecuali konsentrasi 0.2 M terhadap konsentrasi O.3 M. Cha-Um et al. (2010) melaporkan hasil penelitiannya bahwa fotosintesis pigmen klorofil menurun dalam tekanan osmotik pada kultivar padi, berhubungan dengan peningkatan konsentrasi manitol dalam media kultur. Penurunan pigmen klorofil dalam jaringan daun merupakan indikator respon tanaman terhadap tekanan osmotik yang berasal dari manitol. Penambahan dengan konsentrasi yang tinggi memberikan cekaman kekeringan pada media tanam. Kekurangan air pada media tanam dapat mempengaruhi proses-proses biokimia yang berlangsung dalam sel, sehingga proses fotosintesis menurun (Fitter dan Hay, 1994). Klorofil merupakan salah satu aspek fotosintesis yang peka terhadap cekaman kekeringan (Salisbury dan Ross, 1995).

Tabel 4. Pengaruh Mandiri Faktor Konsentrasi Manitol pada Karakter Pertambahan Tinggi Planlet

\begin{tabular}{cc}
\hline $\begin{array}{c}\text { Konsentrasi } \\
\text { Manitol }\end{array}$ & $\begin{array}{c}\text { Pertambahan Tinggi Planlet } \\
(\mathbf{c m})\end{array}$ \\
\hline $0.0 \mathrm{M}\left(\mathrm{m}_{1}\right)$ & $8.6 \mathrm{~d}$ \\
$0.1 \mathrm{M}\left(\mathrm{m}_{2}\right)$ & $3.9 \mathrm{c}$ \\
$0.2 \mathrm{M}\left(\mathrm{m}_{3}\right)$ & $1.9 \mathrm{~b}$ \\
$0.3 \mathrm{M}\left(\mathrm{m}_{4}\right)$ & $1.1 \mathrm{~b}$ \\
$0.4 \mathrm{M}\left(\mathrm{m}_{5}\right)$ & $0.4 \mathrm{a}$
\end{tabular}

$\overline{\text { Keterangan : Nilai rata-rata yang ditandai dengan huruf }}$ yang sama pada kolom yang sama menunjukkan tidakberbeda nyata menurut uji jarak berganda duncanpada taraf 5\%

Tabel 5. Pengaruh Mandiri Faktor Konsentrasi Manitol pada Karakter Konsentrasi Klorofil Daun

\begin{tabular}{cc}
\hline $\begin{array}{c}\text { Konsentrasi } \\
\text { Manitol }\end{array}$ & Konsentrasi Klorofil $(\boldsymbol{\mu m o l})$ \\
\hline $0.0 \mathrm{M}\left(\mathrm{m}_{1}\right)$ & $1.71 \mathrm{ab}$ \\
$0.1 \mathrm{M}\left(\mathrm{m}_{2}\right)$ & $1.51 \mathrm{ab}$ \\
$0.2 \mathrm{M}\left(\mathrm{m}_{3}\right)$ & $1.91 \mathrm{~b}$ \\
$0.3 \mathrm{M}\left(\mathrm{m}_{4}\right)$ & $1.31 \mathrm{a}$ \\
$0.4 \mathrm{M}\left(\mathrm{m}_{5}\right)$ & $1.29 \mathrm{a}$
\end{tabular}

$\overline{\text { Keterangan : Nilai rata-rata yang ditandai dengan huruf }}$ yang sama pada kolom yang sama menunjukkan tidakberbeda nyata menurut uji jarak berganda duncanpada taraf $5 \%$

Pengamatan jumlah akar dilakukan pada akhir pengamatan (6 MSP). Berdasarkan hasil uji $\mathrm{F}$ terlihat bahwa faktor kultivar kentang dan manitol secara mandiri berpengaruh sangat nyata pada karakter jumlah akar terbentuk. Tabel 6. menunjukkan bahwa kultivar Merbabu 17 menghasilkan jumlah akar terbanyak dibandingkan kultivar lain yang diuji, namun tidak berbeda nyata dengan kultivar Granola, sedangkanpenambahan manitol hingga konsentrasi o.2 M belum memberikan pengaruh nyata terhadap jumlah akar yang terbentuk. Penurunan jumlah akar baru terjadi pada konsentrasi $0.3 \mathrm{M}$ dan $0.4 \mathrm{M}$. Perbedaan nilai rata-rata jumlah pembentukan akar dari kultivar Granola, Atlantik, Andina, Ping 06, Merbabu 17, diduga karena setiap kultivar memiliki kemampuan yang berbeda dalam menghasilkan fitohormon. 
Tabel 6. Pengaruh Mandiri Faktor Kultivar Kentang dan Konsentrasi Manitol pada Karakter Jumlah Akar

\begin{tabular}{|c|c|}
\hline Kultivar & $\begin{array}{c}\text { Jumlah Akar } \\
\text { Terbentuk }\end{array}$ \\
\hline Granola $\left(\mathrm{k}_{1}\right)$ & $5.7 \mathrm{ab}$ \\
\hline Atlantik $\quad\left(\mathrm{k}_{2}\right)$ & $5.2 \mathrm{a}$ \\
\hline Andina $\quad\left(k_{3}\right)$ & $5.4 \mathrm{a}$ \\
\hline Ping $06 \quad\left(k_{4}\right)$ & $4.9 \mathrm{a}$ \\
\hline Merbabu $17\left(\mathrm{k}_{5}\right)$ & $6.7 \mathrm{~b}$ \\
\hline Konsentrasi Manitol & $\begin{array}{c}\text { Jumlah Akar } \\
\text { Terbentuk }\end{array}$ \\
\hline $0.0 \mathrm{M}\left(\mathrm{m}_{1}\right)$ & $6.5 \mathrm{~b}$ \\
\hline $0.1 \mathrm{M}\left(\mathrm{m}_{2}\right)$ & $6.8 \mathrm{~b}$ \\
\hline $0.2 \mathrm{M}\left(\mathrm{m}_{3}\right)$ & $5.8 \mathrm{~b}$ \\
\hline $0.3 \mathrm{M}\left(\mathrm{m}_{4}\right)$ & $4.2 \mathrm{a}$ \\
\hline $0.4 \mathrm{M}\left(\mathrm{m}_{5}\right)$ & $4.6 \mathrm{a}$ \\
\hline
\end{tabular}

Keterangan: Nilai rata-rata yang ditandai dengan huruf yang sama pada kolom yang sama menunjukkan tidakberbeda nyata menurut uji jarak berganda duncan pada taraf $5 \%$

Pengamatan panjang akar dilakukan pada akhir penelitian (6 MSP). Hasil uji-F terhadap karakter panjang akar terbentuk tidak terdapat interaksi antara faktor manitol dan kultivar. Faktor kultivar kentang dan faktor konsentrasi manitol secara mandiri berpengaruh secara nyata secara nyata pada karakter ini.

Berdasarkan hasil uji jarak berganda Duncan yang tersaji pada Tabel 7, terlihat bahwa kultivar Merbabu 17 menghasilkan panjang akar yang tidak berbeda nyata dengan kultivar lainnya, kecuali dengan kultivar Ping 06. Pengaruh mandiri faktor konsentrasi manitol terhadap karakter panjang akar menunjukkan bahwa konsentrasi manitol 0.4 M menghasilkan akar yang terpendek dibandingkan konsentrasi manitol lainnya. Meningkatnya konsentrasi manitol dapat mempengaruhi panjang akar.Pertumbuhan akar yang intensif merupakan kemampuan suatu tanaman untuk beradaptasi pada kondisi cekaman kekeringan (Wu dan Cosgrove, 2000).

Pengamatan perubahan warna daundiamati setiap satu minggu sekali sejak awal percobaan hingga akhir percobaan. Tabel 8 menunjukkan perubahan warna daun mulai terjadi pada saat 1 MSP sampai 4 MSP. Perubahan warna pada 1 MSP pada umumnya terjadi pada perlakuan konsentrasi manitol sebesar 0.3 $\mathrm{M}$ dan 0.4 M. Perlakuan konsentrasi 0.0 M tidak mengakibatkan perubahan warna daun pada semua kultivar.

Kultivar yang mengalami perubahan warna daun tercepat adalah kultivar Granola. Kultivar Granola mengalami perubahan warna pada minggu pertama akibat penambahan konsentrasi manitol $0.3 \mathrm{M}$ dan 0.4 M. Selanjutnya terjadi perubahan warna pada minggu kedua pada penambahan manitol $0.1 \mathrm{M}$ dan $0.2 \mathrm{M}$. Kultivar Merbabu 17 merupakan kultivar yang mengalami respon perubahan warna daun paling lambat diantara kultivar lainnya. Kultivar Merbabu 17 mulai menunjukkan respon perubahan warna daun pada minggu kelima pada perlakuan konsentrasi manitol sebesar $0.2 \mathrm{M}, 0.3 \mathrm{M}$ dan 0.4 M. Tidak terjadi respon perubahan warna daun pada perlakuan 0.0 M, dan 0.1 M pada kultivar Merbabu 17.

Tabel 7. Pengaruh Mandiri Faktor Kultivar Kentang dan Manitol pada Karakter Panjang Akar

\begin{tabular}{|c|c|}
\hline Kultivar & $\begin{array}{c}\text { Panjang } \\
\text { Akar }(\mathrm{cm})\end{array}$ \\
\hline Granola $\quad\left(k_{1}\right)$ & $10.4 \mathrm{ab}$ \\
\hline Atlantik $\quad\left(\mathrm{k}_{2}\right)$ & $12.5 \mathrm{ab}$ \\
\hline Andina $\quad\left(k_{3}\right)$ & $13.2 \mathrm{ab}$ \\
\hline Ping $06 \quad\left(k_{4}\right)$ & $10.5 \mathrm{a}$ \\
\hline Merbabu $17\left(\mathrm{k}_{5}\right)$ & $13.6 \mathrm{~b}$ \\
\hline $\begin{array}{c}\text { Konsentrasi } \\
\text { Manitol }\end{array}$ & $\begin{array}{c}\text { Panjang } \\
\text { Akar }(\mathbf{c m})\end{array}$ \\
\hline $0.0 \mathrm{M}\left(\mathrm{m}_{1}\right)$ & $15.9 \mathrm{~cd}$ \\
\hline $0.1 \mathrm{M}\left(\mathrm{m}_{2}\right)$ & $18.2 \mathrm{~d}$ \\
\hline $0.2 \mathrm{M}\left(\mathrm{m}_{3}\right)$ & $14.2 \mathrm{c}$ \\
\hline $0.3 \mathrm{M}\left(\mathrm{m}_{4}\right)$ & $7.8 \mathrm{~b}$ \\
\hline $0.4 \mathrm{M}\left(\mathrm{m}_{5}\right)$ & $4.1 \mathrm{a}$ \\
\hline
\end{tabular}

$\overline{\text { Keterangan : Nilai rata-rata yang ditandai dengan huruf }}$ yang sama pada kolom yang sama menunjukkan tidakberbeda nyata menurut uji jarak berganda duncanpada taraf $5 \%$

Terjadinya perubahan warna daun pada lima kultivar kentang dikarenakan manitol membatasi ketersediaan air. Keterbatasan air mempengaruhi keseimbangan kimiawi dalam tanaman. Keterbatasan air mengakibatkan terganggunya fotosintesis dan hasil fotosintesis atau proses-proses fisiologis tanaman tidak berjalan dengan baik (Suharjanto, 2010).

Pengamatan kerusakan planlet dilakukan pada akhir percobaan. Kerusakan eksplan diamati dengan cara skoring. Lima kultivar kentang memiliki kerusakan yang berbeda yang disebabkan oleh perlakuan konsentrasi manitol. Berdasarkan Tabel 9 terlihat bahwa setelah dilakukan skoring kerusakan akibat penambahan manitol pada mediakultur, diketahui bahwa rata-rata kerusakan pada planlet berkisar antara 25\% sampai dengan $75 \%$. Umumnya kerusakan pada planlet terjadi karena penambahan konsentrasi manitol sebesar $0.2 \mathrm{M}$; 0.3M dan 0.4 M. Kerusakan tertinggi terjadi pada kultivar Ping 06 mencapai skor 4 pada konsentrasi mannitol 0.4 M. Kultivar Merbabu 17 mengalami kerusakan skor 2 (25-50\%) pada perlakuan $0.3 \mathrm{M}$, berbeda dengan kultivar lainnya yang sudah mengalami kerusakan 
skor $3(50-75 \%)$ pada media perlakuan manitol sebesar

$0.3 \mathrm{M}$.

Tabel 8. Perubahan Waktu Daun Menguning (MSP) Kelima Kultivar Kentang yang Diuji pada Kelima Konsentrasi Manitol yang Digunakan

\begin{tabular}{cccccc}
\hline Kultivar & \multicolumn{5}{c}{ Perlakuan } \\
\cline { 2 - 6 } & $\begin{array}{c}\mathbf{0 . 0 ~ M} \\
\left(\mathbf{m}_{1}\right)\end{array}$ & $\begin{array}{c}\mathbf{0 . 1} \mathbf{M} \\
\left(\mathbf{m}_{2}\right)\end{array}$ & $\begin{array}{c}\mathbf{0 . 2} \mathbf{M} \\
\left(\mathbf{m}_{3}\right)\end{array}$ & $\begin{array}{c}\mathbf{0 . 3} \mathbf{M} \\
\left(\mathbf{m}_{4}\right)\end{array}$ & $\begin{array}{c}\mathbf{0 . 4} \mathbf{M} \\
\left(\mathbf{m}_{5}\right)\end{array}$ \\
\hline Granola & - & 2 & 2 & 1 & 1 \\
Atlantik & - & - & 2 & 1 & 1 \\
Andina & - & - & 4 & 4 & 4 \\
Ping 06 & - & - & 5 & 5 & 4 \\
Merbabu 17 & - & - & 5 & 5 & 5 \\
\hline Keterangan: - Daun tidak menguning; $\mathrm{m}_{1}$ - Manitol o.oM; $\mathrm{m}_{2=}$ Manitol 0.1 M; $\mathrm{m}_{3=}$ Manitol 0.2 M; $\mathrm{m}_{4=}$ Manitol 0.3 \\
M; $\mathrm{m}_{2=}$ Manitol 0.4 M
\end{tabular}

Tabel 9. Rata-rata Skor Kerusakan Planlet Lima Kultivar Kentang pada Lima Konsentrasi Manitol yang Digunakan

\begin{tabular}{cccccc}
\hline Kultivar & \multicolumn{5}{c}{ Perlakuan } \\
\cline { 2 - 6 } & $\begin{array}{c}\mathbf{0 . 0} \mathbf{M} \\
\left(\mathbf{m}_{\mathbf{1}}\right)\end{array}$ & $\begin{array}{c}\mathbf{0 . 1} \mathbf{M} \\
\left(\mathbf{m}_{2}\right)\end{array}$ & $\begin{array}{c}\mathbf{0 . 2} \mathbf{M} \\
\left(\mathbf{m}_{3}\right)\end{array}$ & $\begin{array}{c}\mathbf{0 . 3} \mathbf{M} \\
\left(\mathbf{m}_{4}\right)\end{array}$ & $\begin{array}{c}\mathbf{0 . 4} \mathbf{M} \\
\left(\mathbf{m}_{5}\right)\end{array}$ \\
\hline Granola & 0 & 0 & 2 & 3 & 3 \\
Atlantik & 0 & 0 & 2 & 3 & 3 \\
Andina & 0 & 1 & 2 & 3 & 3 \\
Ping 06 & 0 & 0 & 2 & 3 & 4 \\
Merbabu 17 & 0 & 0 & 1 & 2 & 3 \\
\hline
\end{tabular}

Persentase kerusakan 5\% sampai dengan 25\% menunjukkan bahwa planlet dapat bertahan hidup pada media dengan penambahan manitol, jumlah akar dan panjang akar bertambah namun tidak sebanyak planlet yang hidup pada media tanpa manitol. Selain itu, ujung daun sedikit menguning pada 4 MSP. Persentase kerusakan 25-50\% umumnya terjadi karena penambahan manitol sebanyak $0.2 \mathrm{M}$, terlihat bahwa beberapa daun mulai menguning, pertambahan tinggi planlet lambat, dan pembentukan jumlah serta panjang akar berkurang. Kerusakan yang terjadi akibat penambahan konsentrasi manitol sebesar $0.2 \mathrm{M}$ dialami oleh semua kultivar. Pertumbuhan tinggi planlet yang dipengaruhi oleh manitol konsentrasi manitol sebesar $0.2 \mathrm{M}, 0.3 \mathrm{M}$ dan $0.4 \mathrm{M}$ terlihat terhambat dibandingkan dengan planlet yang tumbuh pada media tanpa manitol.

Persentase kerusakan 50\% sampai dengan $75 \%$ dialami oleh semua kultivar akibat penambahan manitol sebesar 0.3 M dan 0.4 M. Planlet tanaman memberikan respon seperti permukaan daun menguning, jumlah daun berkurang, jumlah dan panjang akar menurun, dan tinggi planlet lambat. Kerusakan ini mulai terlihat terjadi pada saat 4 MSP. Terdapat beberapa planlet dengan skor kerusakan sebesar $75 \%$ sampai dengan $100 \%$, diakibatkan penambahan manitol sebesar 0.4 M. Kerusakan ini terjadi pada kultivar Pingo6. Manitol digunakan sebagai agen penyeleksi dalam membuat kondisi cekaman kekeringan. Hadi et al. (2014) melaporkan terjadi penurunan panjang akar pada tanaman tomat dan bunga kol dengan penambahan agen penyeleksi manitol. Manitol memberikan pengaruh lebih nyata dalam penurunan panjang akar dibandingkan agen penyeleksi lain seperti Polyethylene Glycol (PEG). Akar merupakan indikator resistensi tanaman dalam menghadapi cekaman kekeringan. Nio Song Ai dan Torey (2013) menjelaskan bahwa akar memiliki peran dalam menghadapi kondisi lingkungan kurang air dengan mengurangi laju transpirasi. Pertumbuhan akar terhambat pada lingkungan kurang air, karena sel-sel tanaman tidak dapat mempertahankan turgor yang diperlukan untuk pemanjangan akar. Penambahan manitol dalam media kultur memberikan simulasi cekaman kekeringan. Kondisi cekaman kekeringan menghambat kemampuan akar dalam penyerapan air dan unsur-unsur hara, sehingga akar tidak dapat mentranslokasikan unsur-unsur hara menuju daun (Harjadi dan Yahya, 1988).

Kerusakan planlet akibat penambahan manitol dapat dilihat dengan adanya warna kuning pada permukaan daun, tinggi tanaman terhambat, panjang dan jumlah akar menurun. Kultivar Ping 06 merupakan kultivar yang memiliki skor kerusakan tertinggi sebesar 4. Kultivar Ping 06 mengalami kerusakan pada penambahan konsentrasi manitol sebesar 0.2 M sampai dengan 0.4 M.

\section{Kesimpulan Dan Saran}

Tidak terdapat interaksi antara lima kultivar kentang dengan konsentrasi manitol yang diberikan sebagai simulasi cekaman kekeringan pada kultur in vitro.Terdapat pengaruh mandiri faktor kultivar kentang dengan manitol terhadap semua karakter, kecuali karakter pertambahan tinggi dan konsentrasi 
klorofil, kedua karakter hanya dipengaruhi secara mandiri oleh faktor manitol. Konsentrasi manitol 0.4 M mengakibatkan penurunan pada karakter jumlah daun, jumlah buku planlet, tinggi tanaman, konsentrasi klorofil, jumlah akar, panjang akar, warna daun, skoring kerusakan planlet pada lima kultivar kentang yang diuji bila dibandingkan dengan konsentrasi lainnya.

\section{Daftar Pustaka}

Cha-Um, S., N.T.H. Nhung, and C. Kirdamanee. 2010. Effect of mannitol and salt-induced isoosmotic stress on proline accumulation, photosynthetic abilities, and growth characters of rice cultivars (Oryza Sativa L. Spp Indica). Pak. J. Bot., 42(2): 927-941.

Duncan, R.R., R.M. Waskom, and M.W. Nabors. 1995. In vitro screening and field evaluation of tissue culture regenerated sorghum (Sorghum bicolor L. Moench) for stress tolerance. Euphytica (85): 373-380.

Fitter, A.H. dan R.K.M. Hay. 1994. Fisiologi Lingkungan Tanaman. Gadjah Mada University Press. Yogyakarta.

Hadi, F., M. Ayaz, S. Ali, Shafiq, M., R. Ullah, and A.U. Jan. 2014. Comparative effect of polyethylene glycol and mannitol induced drought on growth (in vitro) of canola (Brassica napus), cauliflower (Brassica oleracea) and tomato (Lycopersicon esculentum) seedlings. International Journal of Biosciences (IJB). Vol. 4 (9): 34-41.

Harjadi S S, dan S. Yahya S. 1988. Fisiologi stress lingkungan. IPB, Bogor

Husna, A.U, L. Siregar, M. Husni. 2014. Pertumbuhan dan pekembangan nodus kentang (Solanum tuberosum L.) akibat modifikasi konsentrasi sukrosa dan penambahan 2-isopenteniladenina secara in vitro. Jurnal Agroekoteknologi. Vol.2(3): 9971003

Karjadi, A.K. 2006. Produksi Benih Kentang Berkualitas. Iptek Hortikultura. Balai Tanaman Sayuran.
Mitoi, E.M., I. Holobiuc, and R. Blindu, 2009. The effect of mannitol on antioxidative enzymes in vitro long term cultures of Dianthus tenuifolius and Dianthus spiculifolius. Rom. J. Biol.-Plant Biol., Vol 54 (1): 25-33.

Nio Song Ai, dan P.Torey. 2013. Karakter morfologi akar sebagai indikator kekurangan air pada tanaman. Jurnal Bioslogos Vol. 3 (1): 31-39

Passioura J.B., and S.C. Fry. 1992. Turgor and cell expansion: beyond the Lockhart equation. Aust. J. Plant Physiol. 19: 565-579.

Roostika, I., Purnamaningsih, R. Supriati, Y. Mariska, I. Khumaida, N. dan Wattimena, GA . 2012. Pembentukan benih sintetik tanaman nenas. J.Hort. 22(4):316-326.

Rubatzky, V.E., dan Yamaguchi, M. 1998. Sayuran dunia: Prinsip, Produksi , dan Gizi Jilid I., Penerbit ITB. Bandung.

Salisbury, F.B. and C.W. Ross. 1995. Fisiologi Tumbuhan. Jilid I. Penerbit ITB, Bandung.

Suharjanto,T. 2010. Respon hasil kacang komak terhadap intensitas cekaman kekeringan. Agrika, Volume 4 (1):

Vitova,L., E. Stodulka, A. Bartonickova, and H. Lipavska. 2002. Mannitol utilisation by celery (Apium graveolens) plants grow under different conditions in vitro. J. Plant Science 163: $907-919$

Wattimena, G.A. N.A. Mattjik, E. Syamsudin, Ernawati. 1992. Bioteknologi Tanaman. Laboratorium Kultur Jaringan Tanaman. Pusat Antar Universitas. IPB Bogor.

Wu Y. and D.J. Cosgrove. 2000. Adaptation of root to low water potential by change in cell extensibility and cell wall proteins. J.of Experimental Bot. Vol. 51(350): 1543-1553

Zang, L. and S. Komatsu. 2007. A proteomics approach for identifying osmotic-stressrelated proteins in rice. Phytoche., 68: 426437. 